\title{
Kääntäjien kirjeenvaihto, suomentamisen normit ja kieli-ideologiat 180o-luvun lopun Suomessa
}

\author{
TARU NORDLUND
}

\section{Kirjeenvaihto ja historialliset käännösprosessit}

Tarkastelen tässä artikkelissa kääntämisen prosesseja 180o-luvun Suomessa yksittäisten kääntäjien näkökulmasta. Tutkimuksen kohteena eivät siis ole valmiit käännöstekstit, niiden suhde lähtöteksteihinsä tai tekstien vastaanotto vaan prosessi, jossa käännös syntyy. Tutkimus keskittyy kolmeen kääntäjään, jotka toimivat Werner Söderström Osakeyhtiön kustantamossa 180o-luvun lopulla. Pääasiallisena tutkimusaineistona on kääntäjien ja kustantajan välinen kirjeenvaihto. Tutkimuksen pyrkimyksenä on selvittää, mitkä ideologiset, sosiaaliset tai henkilökohtaiset tekijät ohjasivat yksittäistä kääntäjää erilaisissa valintatilanteissa. ${ }^{1}$

Kääntämisen prosessin tarkastelu siirtää näkökulman itse käännöksestä (translation product) erilaisiin toimijoihin, joita ovat kääntäjän lisäksi esimerkiksi kustantaja, asiantuntija ja kielenhuoltaja. Eri toimijoihin keskittyminen johtaa tarkastelemaan kääntämistä moniäänisenä prosessina, jossa voidaan erottaa ensinnäkin itse tekstissä esiintyvät alkutekstin kirjoittajan ja kääntäjän äänet (textual voices) sekä varsinaisen käännöstekstin ulkopuoliset ja sitä kontekstualisoivat äänet (contextual voices). Jälkimmäisiä ovat muun muassa esipuheet, arvostelut, käännöksiä koskevat debatit sekä käännösprosessiin liittyvä kirjeenvaihto tai muu toimijoiden välinen yhteydenpito. (Alvstad, Greenall, Jansen \& Taivalkoski-Shilov toim. 2017: 1-15.)

Kirjeenvaihto - sekä institutionaalinen että henkilökohtainen - avaa tutkijalle ainutlaatuisen pääsyn toisen henkilön sisäiseen ja ulkoiseen maailmaan (esim. Nordlund 2013; Laitinen \& Nordlund 2012). Kirjeissään kääntäjät pohtivat, perustelevat, puolustelevat ja erittelevät kääntämiseen ja kieleen liittyviä ongelmia, joita he ovat työssään koh-

1. Kiitän Virittäjän nimettömiä arvioijia tarkkanäköisistä huomioista. Erityiskiitos toiselle refereelle myös teoreettista taustaa tarkentavista käännöstieteellisistä huomiosta. Tutkimus on toteutettu Koneen Säätiön rahoittamassa tutkimushankkeessa Suomentamisen ideologiat ja normit: tietokirjallisuuden konventioiden muotoutuminen ja keskustelu käännösten kielestä 1800- ja 2000-luvuilla. Lämpimät kiitokset inspiroivista keskusteluista ja tuesta hankkeen tutkijoille Jyrki Kalliokoskelle, Lea Laitiselle, Petri Lauermalle, Anne Mäntyselle ja Kaarina Pitkänen-Heikkilälle. Kiitän myös Outi Paloposkea käymistämme 1800-luvun kääntämistä koskevista keskusteluista sekä jaetuista lähteistä ja aineistoista. 
danneet. Ongelmat voivat liittyä käytännön asioihin, kuten kääntäjän asemaan, käännöksen merkitykseen tai vastaanottajaan, tai kielen tasolla kielelliseen merkitykseen tai muotoon. Tämä kääntämisen prosessin kielellistäminen avaa erilaisia murtumakohtia, jotka tutkijan näkökulmasta toimivat sisäänkäynteinä kääntämisen taustalla oleviin normeihin ja ideologioihin.

Tutkimusaineistona toimii Werner Söderström Osakeyhtiön arkiston kirjailijoiden ja yhtiön johdon välinen kirjeenvaihto 1880-luvulta 1900-luvun ensi vuosikymmenen loppuun. ${ }^{2}$ Lähemmän analyysin kohteet, kääntäjät Niilo E. Wainio, Aatto Suppanen ja Hilda Käkikoski, valikoituivat tutkimukseen kirjeenvaihdon laajuuden perusteella. Käkikoskelta on tutkimusta varten käyty läpi myös henkilökohtaista kirjeenvaihtoa, jota säilytetään Suomalaisen Kirjallisuuden Seuran arkiston kirjallisuuden ja kulttuurihistorian kokoelmassa. ${ }^{3}$ Joissakin kohdin kirjeaineiston lisäksi viittaan käännetyissä teoksissa esiintyviin varsinaisen tekstin ulkopuolisiin osiin, kuten esipuheisiin tai kääntäjien kommentteihin, sekä teosten ulkopuolisiin teksteihin, kuten käännöskritiikkiin tai lehtikeskusteluihin. Nämä varsinaisen leipätekstin ulkopuoliset tekstit valaisevat kääntämisen normeja ja normikeskustelun moniäänisyyttä. Analyysi kohdistuu siis siihen metatasoon, jolla keskustelua normeista tai ideologioista käydään. Kieli- tai käännösideologioiden purkamiseksi on metatason kommentteja joissakin kohdin peilattu myös itse tekstiaineistoihin, joita löytyy Kotimaisten kielten keskuksen Kaino-tekstikorpuksesta ja Kansalliskirjaston digitaalisesta sanomalehtiarkistosta sekä käännettävistä teoksista. Tällainen tarkastelu mahdollistaa metatason vertailun teksteistä itsestään luettavissa oleviin normeihin ja ideologioihin.

\section{Kääntämisen historia, kääntämisen historiallinen sosiologia ja kirja- kielen tutkimus}

Kääntäjien ja kustantajan välinen kirjeenvaihto kertoo pääasiassa kääntämisen todellisista ja materiaalisista olosuhteista 1800 -luvun lopulla. Artikkelini sivuaa näin ollen läheisesti myös tutkimusta kääntäjien työstä ja asemasta tuona aikana (esim. Paloposki 2001, 2013; Saarikivi 2005). Koska kirjeenvaihto ajoittuu 1800-luvun loppupuolelle, myös tietokirjallisuuden suomentamisen historia (Paloposki \& Riikonen 2013) ja kustantamisen historia Suomessa (esim. Häggman 2001, 2008; Paloposki 2013) toimivat tutkimuksen tärkeänä taustatietona.

Tutkimuskohteena on koko kääntämisprosessi (translation in the making), ei pelkästään lopputulos eli itse käännösteksti. Tämä kytkee tutkimuksen kääntämisen sosiologian tutkimukseen, joka tarkastelee kääntämistä suhteessa sosiaaliseen ja yhteiskunnalliseen kontekstiin. Tällaisessa käännöstutkimuksessa näkökulma on kielellisten kysymyksenasetteluiden sijasta esimerkiksi käännösten tai kääntäjien yhteiskunnallisessa

2. Kirjeenvaihtoa säilytetään Päivälehden museossa Helsingissä. Olen käynyt läpi säilyneen kirjeenvaihdon ja kirjekonseptit vuosilta 1880-1910, ja noin 80 kirjeessä kääntäjät tai kustantaja kommentoivat nimenomaan kieltä ja kääntämistä.

3. Kiitän lämpimästi tutkimusavustajaani fil. maist. Hanna Lehtosta, joka kävi läpi Hilda Käkikosken arkiston Suomalaisen Kirjallisuuden Seuran arkistossa. 
asemassa. (Chesterman 2007.) Kääntämisen prosessia voidaan valottaa analysoimalla erilaisissa työvaiheissa syntyviä dokumentteja, jollaisia ovat toimijoiden välinen kirjeenvaihto, kustannussopimukset, markkinoinnissa käytetty materiaali ja kommentoidut käsikirjoitusversiot käännöksistä. Nykykääntämisen tutkija voi lisäksi käyttää tutkimusmetodina esimerkiksi eri toimijoiden haastatteluja tai etnografista havainnointia. (Buzelin 2007; Mäntynen \& Kalliokoski 2018 tässä teemanumerossa.) Aineistona voi toimia myös kääntäjän, asiantuntijan ja kustannustoimittajan vuoropuhelu käännösten käsikirjoituksissa. Sen perusteella voidaan analysoida kunkin osallistujan mahdollisuuksia vaikuttaa käännösprosessiin ja sen lopputulokseen sekä paljastaa erilaisia valtasuhteita osallistujien välillä. (Mäntynen 2012; Siponkoski 2014.)

Kääntämisen historian tutkimus on sekä kansainvälisesti että Suomessa tuonut esille kääntäjät, jotka ovat etenkin kirjakielten varhaisemmissa vaiheissa usein olleet varsin näkymättömiä toimijoita (Paloposki 2001; Saarikivi 2005; Pym 1998). ${ }^{4}$ Käännöstutkija Anthony Pymin (1998: 4-6) mukaan kääntämisen historian tutkimuksen ensisijainen kohde on tekstin kääntäjä, ei käännetty teksti: "kääntämisen arkeologia" pyrkii selvittämään, kuka on kääntänyt mitä, miten, missä ja kenelle sekä miten käännös on vastaanotettu. Sosiaalista kontekstia analysoimalla voidaan toisin sanoen selvittää, miksi tietyt käännökset on tuotettu tiettynä aikana ja tietyssä paikassa. Pymin (mts. 16) mukaan historian tutkimus saa motivaationsa nykyisyydestä ja sillä on linkki tähän aikaan; sitä motivoivat kysymykset ja ongelmat, jotka nousevat nykykäännösten tutkimuksesta: "menneisyyden syvempi tuntemus voi antaa meille laajemman taustan arvioida tulevaisuutta" (suom. kirjoittajan). Yksi tapa analysoida kääntämisen yhteiskunnallisia kytköksiä diakronisesta näkökulmasta on uudelleenkäännösten tarkastelu. Suomessa erityisesti Kaisa Koskinen ja Outi Paloposki (2015: 15-25) ovat erilaisten kvantitatiivisten metodien sekä tapaustutkimusten avulla luoneet kokonaiskuvaa uudelleenkääntämisestä ilmiönä. Uudelleenkäännösten tarkastelu edustaa niin kutsuttua kääntämisen historiallista sosiologiaa (mts. 24), jonka pyrkimyksenä on tulkita kääntäjien valintoja aikakauden yhteiskunnallista, poliittista ja kieli-ideologista taustaa vasten.

Kääntäjällä on tekstiä kääntäessään mahdollisuus päätyä monenlaisiin käännösratkaisuihin; myös käännösihanteet ovat vaihdelleet eri aikakausina. Kääntämisen normit ovat sääntöjä tai ohjeita, jotka ohjaavat kääntäjää valitsemaan ratkaisunsa kaikista olemassa olevista potentiaalisista käännösratkaisuista (ks. esim. Toury 2012 [1995]; Chesterman 2007; Kujamäki 2013). Kääntämistä ohjaavat normit kietoutuvat monella tapaa kieli-ideologioihin, joilla tarkoitetaan kieliä ja kielimuotoja koskevia käsityksiä ja asenteita - esimerkiksi sitä, miten eri kielimuotoja arvotetaan ja miten eri kielimuotojen välisiä suhteita ja rajoja hahmotetaan (ks. esim. Mäntynen, Halonen, Pietikäinen \& Solin 2012).

Suomen kirjakielen kehittämisen historia jaetaan perinteisesti kahteen erilliseen kauteen, vanhaan kirjasuomeen ja varhaisnykysuomeen. Varhaisnykysuomen ai-

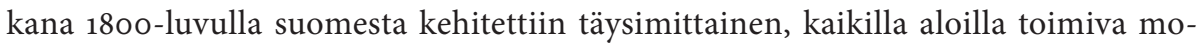

4. Vrt. kuitenkin Paloposki (2008), joka osoittaa, että esipuheiden ja alaviitteiden kautta 1800-luvun kääntäjä on ollut monessa kohdin myös hyvin näkyvä toimija. 
derni kirjakieli. Kirjakielen kehitys kytkeytyi läheisesti kansallisuusaatteeseen, kun suomen kielestä rakennettiin tietoisesti kansallisvaltio Suomen keskeistä symbolia. Kielen kytkeminen kansallisuuteen on ideologinen teko, joka oli luonteenomaista 180o-luvulle, mutta samaa on nähtävissä myös nykyään vähemmistökielten emansipoitumisena eri puolilla maailmaa. Suomen nykyisen kirjakielen perusta luotiin siis varsin lyhyen ajan kuluessa $1800-$ luvulla. Standardisointiprosessia onkin mahdollista tarkastella poikkeuksellisen läheltä, esimerkiksi analysoimalla sanoma- ja aikakauslehdissä, teosten esipuheissa, kieliopeissa, kirja-arvioissa tai yksityisessä ja virallisessa kirjeenvaihdossa käytyä kielikeskustelua. ${ }^{5}$ Toisaalta esimerkiksi kehittyvän kirjakielen todellista vaihtelua on mahdollista analysoida suoraan tekstiaineistosta, muun muassa Kansalliskirjaston Historiallisesta sanomalehtikirjastosta, josta löytyvät digitoituina kaikki suomalaiset sanomalehdet 1900-luvun alkuvuosikymmenille saakka. ${ }^{6}$

Käsittelen seuraavaksi käännöstoiminnan yhteiskunnallista taustaa 180o-luvulla ja esittelen tutkimukseni kohteena olevat kääntäjät (luku 3). Tämän jälkeen kuvaan yleisesti $1800-$ luvun käännösprosessien tutkimuksen aineistoja ja metodologiaa ja siirryn tarkastelemaan lähemmin, millä tavoilla käännösnormit ja kieli-ideologiat tulevat esille omassa aineistossani (luku 4). Loppuluvussa 5 arvioin vielä vuosisadan vaihteen toimijoiden yhteisesti jakamaa kieli-ideologista pohjaa, suomennosprosessien moniäänisyyttä sekä suomentajan asemaa ideologioiden ja arjen ristipaineessa.

\section{Yhteiskunnallinen tausta: kustantajat ja kääntäjät kirjamarkkinoiden toimijoina 1800 -luvun Suomessa}

Kielen ja kääntämisen kulloisetkin ideologiat ja normit ovat aina kytköksissä ympäröivään yhteiskuntaan, kulttuuriin ja sosiaaliseen todellisuuteen. Taustoitan tässä luvussa 180o-luvun loppupuolen kaupallista kustannustoimintaa ja esittelen tutkimukseni keskeiset kolme suomentajaa.

\subsection{Kaupallisen kustannustoiminnan alkaminen 1800-luvun lopussa}

180o-luvun alkupuolella kirjallisuuden tuottaminen ja välittäminen olivat Suomessa aluillaan. Vuosisadan ensimmäisinä vuosikymmeninä perustettiin Turkuun ja sittemmin Helsinkiin lukuisia pitkäikäisiäkin kirjakauppoja ja kirjapainoja. Toimintaan osallistui useita ammattikuntia: kustantajan, kirjanpainajan ja kirjakauppiaan lisäksi keskeisiä olivat muun muassa lumpunkerääjät ja kirjansitojat, joilla oli ollut 170o-luvun

5. Ks. esim. artikkeleita teoksessa Huumo, Laitinen \& Paloposki toim. 2004.

6. Tällä hetkellä Kansalliskirjaston palvelussa ovat avoimesti saatavilla kaikki Suomessa painetut sanomalehdet vuosilta 1771-1929. Tekstejä julkaistaan avoimesti sitä mukaa, kun ne vapautuvat tekijänoikeuksista, ja myös palvelun hakuominaisuuksia kehitetään jatkuvasti. Kansalliskirjasto, Kopiosto, opetus- ja kulttuuriministeriö ja kuusi korkeakoulujen organisaatiota ovat lisäksi aloittaneet kesällä 2018 pilottihankkeen sanoma-ja aikakauslehtien tutkimuskäytön edistämiseksi. Pilottihankkeeseen osallistuvien organisaatioiden käyttäjät pääsevät lukemaan aineistoja ajanjaksolta 1930-2010 Haka-kirjautumisen jälkeen. 
jälkipuoliskolle saakka yksinoikeus kirjojen myyntiin. (Hakapää 2004: 19-24.) Vuosisadan loppuun saakka oli tyypillistä, että sama henkilö saattoi tilapäisesti toimia niin kirjan kustantajana, painajana kuin kirjakauppiaanakin (mt.; Häggman 2008: 83; Paloposki 2007).

180o-luvulla suomalainen yhteiskunta kävi läpi modernistumisen ja teollistumisen murroksen: sääty-yhteiskunnasta siirryttiin kansalaisyhteiskuntaan, ja ihmisten maailmankuva oli muuttumassa uskonnollisesta maallisemmaksi. Vuosisadan puolivälin tienoilta alkanut snellmanilainen kansallinen projekti kasvatti suomenkielistä sivistyneistöä muun muassa kehittyvän koululaitoksen kautta. Kirjojen kustantaminen oli läheisesti kytköksissä yhteiskunnallisiin muutoksiin ja kansan sivistämiseen. Vuosisadan alkupuolella tietokirjallisuuden kustannushankkeet lähtivät kuitenkin vielä pääasiassa liikkeelle yksittäisistä henkilöistä, usein opettajista, jotka tarvitsivat suomenkielistä oppimateriaalia. Keskeisiä olivat myös kansalliset sivistykselliset seurat ja suomen kielen näkökulmasta erityisesti vuonna 1831 perustettu Suomalaisen Kirjallisuuden Seura, jonka toimintaa ohjasi kansallinen ja kansanvalistuksellinen ideologia. (Kovala 2013a: 43-44.)

Yksityisten henkilöiden ja julkisten toimijoiden rinnalle nousivat $1800-l u v u n$ loppupuolella ensimmäiset modernit kirjankustantamiseen keskittyneet yritykset, G. W. Edlund, Weilin \& Göös, Werner Söderström, Gummerus ja Otava. Toiminta kirjamarkkinoilla oli entistä ammattimaisempaa, vaikka kirjallisuus nähtiin yhä myös keskeisenä opetus- ja valistustoiminnan välineenä. (Häggman 2008: 149-161, 187-191; Kovala 2013b; Paloposki 2013.) Werner Söderström Osakeyhtiö perustettiin vuosisadan loppupuolella, vuonna 1878 , jolloin kirjallisuuden instituutiot olivat jo syntyneet ja vakiintuneetkin: suomenkieliselle kirjallisuudelle "alkoi olla tukijoita, lukijoita ja ostajia" (Häggman 2001: XIII). Kustantamon alkuvaiheen menestys oli pitkälti sidoksissa vuosina 1881-1888 ilmestyneen 3 o6o -sivuisen suurteoksen Yleinen ihmiskunnan historia julkaisemiseen. Teos ilmestyi 32 vihkona, se oli runsaasti kuvitettu ja menestyi kaupallisesti hyvin. (Mts. 37-43; 2008: 244-252.) Sanomalehti Kaiun kirjoittaja kommentoi teoksen ilmestymistä seuraavalla tavalla:

(1) Iloista on isänmaanystäwän kokea että yksityiset kirjankustantajat jo yrittäwät näinkin suuria kirjoja painattamaan, johon ei ole tähän asti uskaltanut kuin Suomalainen Kirjallisuuden Seura. Se todistaa, että nuoren kirjallisuutemme wiljelijäin joukko jo on melkoinen. (Kaiku 27.1.1883)

Werner Söderströmiä voidaan pitää Suomen ensimmäisenä ammattimaisena kustannusyhtiönä, joka keskittyi nimenomaan kirjojen kustantamiseen ja kehitti monella tapaa Suomen kirjamarkkinoita (Häggman 2001: 33-34). Keskeisiä uudistuksia olivat muun muassa Yleinen ihmiskunnan historia -teoksen kaltaiset vihkoina myytävät suuret sarjat ja asiamiesverkosto. Kirjojen välittäjiksi eli asiamiehiksi värvättiin laaja kansanjoukko ympäri Suomea. Välittäjinä toimivat tyypillisimmin papit, koulumiehet ja kirkkoherrat mutta myös apteekkarit, nimismiehet ja vauraiden tilojen isännät. Sarjojen lisäksi osa ryhtyi välittämään myös muuta Söderströmin kustantamaa kirjallisuutta, ja vuonna 1895 yhtiöllä oli yhteensä 443 asiamiestä. (Häggman 2001: 43; 2008: 249.) Vä- 
littäjien ja kustantajan välisen kirjeenvaihdon perusteella kauppa ei aina ollut vilkasta eikä kansan lukuhalu korkea:?

(2) a.

Hirvensalmella, Huhtikuun 25 p. 1880

Kunnioitettava Herra!

Kiitän nöyrimmästi ehdoituksestanne, jonka olette minulle tehneet, ja toivotan kaikesta sydämestäni onnea sille isänmaalliselle yrityksellenne, johon olette ryhtyneet! Minä mielelläni rupean asiamieheksenne täällä, vaan pelkään, etten taida siinä hyvin onnistua, kun täällä on kansassa lukuhalu vielä niin rappiolla, mutta parastani tahdon koettaa. [seuraa lista kirjoista] $\mathrm{Ne}$ voisitte lähettää Mikkelin kautta, sillä se on Porvoosta tänne ainoa tie.

Kunnioituksella:

S. Kirjalainen

(S. Kirjalainen Werner Söderströmille 25.4.1880)

b.

- - ettei täällä tahdo kirjat kaupaksi käydä. Olen niitä suositellut kinkereillä, rippilapsille, ja kirkossa kuuluttamalla, mutta enempää kuin se määrä, jota myötä seuraava tili osoittaa, en ole saanut myydyksi. (Niilo Wainio Werner Söderströmille 10.9.1891)

WSOY:n arkistossa johdon kirjeenvaihdon joukosta erottui kolme suomentajaa, joiden kanssa kustantaja kävi kirjeenvaihtoa säännöllisesti ja jotka käsittelivät kirjeissään kieltä ja kääntämistä. Esittelen seuraavassa lähemmin nämä suomentajat.

\subsection{Aatto Suppanen, Niilo Wainio ja Hilda Käkikoski Werner Söderströmin kääntäjinä}

Aatto Suppanen (1855-1898) oli Suomen ensimmäisiä ammattikääntäjiä, ja hän ehti lyhyeksi jääneen uransa aikana suomentaa yli 70 teosta pääasiassa ruotsista ja saksasta. Suppanen oli Werner Söderströmin luottokääntäjä ja työskenteli kustantamossa myös toimitussihteerinä ja kielentarkistajana. Käännöstöiden lisäksi hän toimi Kansallisosakepankin kotimaan kirjeenvaihtajana. (Saarikivi 2005: 83-86; Sorvali 2007.) Suppanen oli tunnettu ja arvostettu. Sanomalehdistössä julkaistiin helmikuussa 1898 hänen muistokirjoituksensa, jossa kiiteltiin hänen ammattitaitoaan ja työtään suomen kielen edistäjänä:

Suomenkielen kehitystä on Suppanen kirjallisella toimellaan suuressa määrässä edistänyt. Hän ei koskaan työssään hutiloinnut. Puhdasta ja sointuwaa on aina kieli

7. Kirjojen hankkiminen oli luonnollisesti myös taloudellinen kysymys. Tarja-Liisa Luukkanen (2016) on käsitellyt lukemista paikallisen kirjaston toiminnan kautta. Kirjastot mahdollistivat lukemisen myös niille, joilla ei ollut mahdollisuutta ostaa kirjoja itselleen. 
ja alkuteoksen luonnetta vastaava. Suomalaisesta kodista lähteneenä osasi Suppanen taitawasti käyttää kielemme runsaita waroja. Monta kaunista wakoa on hän kirjallisuutemme wainiolla kyntänyt ja kunniakkaan sijan tämän kirjallisuudessa saawuttanut. (Uusi Suometar 4.2.1898)

Niilo E. Wainio (1860-1931) oli pappismies, joka toimi kappalaisena ja kirkkoherrana useissa seurakunnissa. Vuodesta 1918 kuolemaansa asti hän oli kirkkoherrana Isossakyrössä. Wainio julkaisi muutaman oman runoteoksen mutta ansioitui ennemminkin unkarilaisen kaunokirjallisuuden ja uskonnollisen kirjallisuuden kääntäjänä. (Riikonen 2013.) Tämän tutkimuksen kirjeenvaihtoaineistossa Wainio keskustelee ja neuvottelee kustantajan kanssa Lutherin elämäkerran käännöksestä.

Hilda Käkikoski (1864-1912) oli historian ja äidinkielen lehtori, naisasia-aktiivi, kääntäjä, kirjailija ja yksi ensimmäisistä suomalaisista naiskansanedustajista. Hän oli kotoisin kaksikielisestä perheestä kaksikieliseltä Uudellamaalta. Ennen poliittista uraansa hän toimi opettajana muun muassa Helsingin Suomalaisessa yhteiskoulussa ja Helsingin Suomalaisessa tyttökoulussa. Jo ennen valmistumistaan opettajaksi Käkikoski toimi myös suomentajana. (Ahtisaari 1997.) Hän suoritti lisäksi historian arvosanan yliopistossa professori E. G. Palménin oppilaana. Historian alalta Käkikoski tunnetaan lapsille ja nuorisolle tarkoitetun historian oppikirjan kirjoittajana. Hän oli saanut vaikutteita erityisesti Sakari Topeliukselta ja Julius Krohnilta, jotka korostivat kertomusten merkitystä oppilaiden mielenkiinnon herättäjänä. (Kaarninen 2013.)

Paitsi itse kääntäjät ja kustantaja kirjeenvaihdossa tulevat näkyväksi myös muut käännösprosessin osallistujat. Kuten katkelmat $3 \mathrm{a}-\mathrm{b}$ kirjeenvaihdosta osoittavat, Werner Söderströmin kustantamien käännöskirjojen kieliasu tarkastutettiin ainakin alkuvaiheessa aina toisella kielen asiantuntijalla. Laadunvalvontaa pidettiin kustantamossa tärkeänä (Häggman 2008: 246; Kovala 2013a: 49).

(3) a.

Suppasen käännöstä tarkastamaan olen puhutellut P. Cajanderia, vielä paljon perinpohjaisempi tarkastus kielellisessäkin suhteessa kuin mihin itse joudan, on huomattu välttämättömäksi, jos mieli saada kirjan suomalainen asu täysin tyydyttäväksi. Olen kuitenkin yhä edelleen minäkin tarkastuksessa osallisena, niin kuin Teille lupasin.

Kunnioituksella

J. R. Danielson

\section{(J. R. Danielson Werner Söderströmille 3.10.189o)}

b. - - ja suurin joukoin kerrassaan ei sellaista työtä haluta tehdä kuin toisten suomennosten korjaaminen on. Pakosta olen sitäkin tehnyt, kun ei ole parempaa työtä ollut; mutta kerrassaan kuolettavaa se on ja sitä paitsi viepi kaksi vertaa aikaa kuin jos itse suomentaisin. - - (A. Suppanen 28.3.1893) 
Kuten edellä oli esillä, Aatto Suppanen toimi kustantamossa paitsi kääntäjänä myös monissa muissa tehtävissä. Edeltävän esimerkin tavoin Suppanen viittaa kirjeenvaihdossaan toistuvasti toisten kääntämien tekstien korjaamisen työläyteen ja vaikeuteen. Käännösten kieliasun tarkistaminen onkin kirjeenvaihdon valossa jo kustantamon alkuvaiheessa systemaattista, ja joistakin lähetetyistä kirjeistä käy ilmi, että käännös on hylätty nimenomaan kieliasun perusteella:

(4) Teidän käännösnäytteitänne Topeliuksen Tarinoista eivät täkäläiset tarkastajat ole hyväksyneet, siinä olevia runoja sitä vastoin pidetään onnistuneina, vaikka tosin jotkut kaipaisivat korjailemista - -. (W. Söderström M. Tammiselle 26.3.1886)

Kääntämistä pidettiin 180o-luvun kirjakielen kehitystyössä keskeisenä kielen rikastuttajana. Varsinkin vuosisadan alkupuolella kääntäjät tulivat aktiivisina toimijoina näkyviin muun muassa teosten esipuheissa, joissa he esittelivät käännösratkaisujaan. Vuosisadan loppupuolella esipuheet alkoivat yhä enemmän käsitellä kirjailijan elämäntyötä ja teosten syntyä, mutta kääntäjät näkyivät kuitenkin yhä muun muassa teoksissa esiintyneissä alaviitteissä. (Paloposki 2008: 5.) Kääntäjän työ tuli luonnollisesti esiin myös teosten vastaanotossa ja kritiikeissä (Paloposki 2004: 42, 50-51). Kääntäjien oma arki paljastuu jäljelle jääneestä kirjeenvaihdosta. Sen valossa kääntäjän työ oli 18ooluvulla kiireistä ja huonosti palkattua: "En tiedä: pitäisikö henkisen työn tekijäin elää tyhjällä tai vesileipäläisen tavoin vai mikä tässä lienee syynä?" (Suppanen, 25.2.1893; ks. myös Saarikivi 2005.) Vaikka palkkioiden pienuus oli kirjeenvaihdon keskeisiä teemoja, avaavat kirjeet myös toiminnan ideologista puolta ja kertovat siitä, miten kääntäjät itsekin kantoivat syvästi vastuuta muun muassa kansallisesta sivistämisen projektista ja suomen kirjakielen rakentamisesta.

\section{Normien ja ideologioiden kielellistäminen}

Toisin kuin nykykäännösten tutkijalla historiallisten käännösten tutkijalla ei luonnollisestikaan ole samanlaisia mahdollisuuksia tarkastella kääntämisen prosessia siinä vaiheessa, kun käännös on juuri syntymässä (vrt. Mäntynen \& Kalliokoski 2018). Tutkijalla on käytettävissään käännetty teksti mutta ei välttämättä edes tarkkaa tietoa sen lähtöteksteistä. 180o-luvulla käännökset olivat monesti Suomen olosuhteisiin ja esimerkiksi kansakoululaitoksen tarpeisiin laadittuja mukaelmia useista eri lähtöteksteistä, jotka olivat usein kaiken lisäksi erikielisiä. Painamattomia käsikirjoitusversioita on työlästä löytää arkistoista, sillä ilmeisesti käytäntönä oli, että käsikirjoitukset tuhottiin, kun painettu teksti ilmestyi (ks. kuitenkin Pitkänen-Heikkilä 2010, 2018 tässä teemanumerossa). Kirjeenvaihdon ja 180o-luvun aineiston kartoittamisen yhteydessä Werner Söderströmin arkistosta löytyi kuitenkin uskonnollinen käsikirjoitus Kääntymys pimeydestä walkeuteen - Ap.t. 9: 1-18, jonka yhteydessä oli myös alkuperäinen ruotsinkielinen teksti En sann omvändelse från mörker till ljus - Tankar öfver Ap.-G. 9, 1-18. Tekstin todennäköinen kääntäjä oli kirkkohistorian professori Herman Råbergh, ja 
käännökseen on tehty muun muassa leksikaalisia, ortografisia ja sanajärjestyksen muutoksia. Ainakin osa korjauksista näyttäisi olevan nimenomaan ruotsinmukaisuuksien muokkaamista, ja käännöstä tarkistanut henkilö on käsikirjoituksen marginaalissa kommentoinut käännöstä liiallisista svetisismeistä.

Vaikka muokattujen käsikirjoitusten jäljittäminen on työlästä, voi 180o-luvun suomennosten tutkija tukeutua monenlaisiin sekundaareihin lähteisiin (Pitkänen-Heikkilä 2010). Tällaisia ovat esimerkiksi kirjoihin painetut esipuheet ja johdannot sekä kääntäjän huomautukset ja jälkilauseet, joissa kääntäjä voi muun muassa informoida lukijaa tekemistään ratkaisuista tai valmistautua tekstin vastaanottoon (Hartama-Heinonen 1995; Paloposki 2008). Kääntäjillä oli 1800-luvulla tärkeä rooli myös vieraiden kulttuurien asiantuntijoina. Muun muassa käyttämällä alaviitteitä he selittivät vieraskielisiä sanoja ja sitaatteja ja tekivät samalla omaa työtään ja valintojaan näkyvämmäksi lukijoille (Paloposki 2008). Tarkastelen seuraavaksi, millä tavoin erilaiset normit ja kieliideologiat näkyvät kääntäjien ja kustantajan kirjeenvaihdossa. Käsittelen aluksi sitä, miten vastaanottajan huomioimisen normi ilmenee aineistossa, ja erittelen sen jälkeen kääntäjien kieli-ideologisia kannanottoja.

4.1 Oppineelle yleisölle vai koko kansalle: vastaanottajan huomioiminen kääntämistä ohjaavana normina

Kääntämisen normit ovat toimintaohjeita, joiden mukaan kääntäjä kussakin tilanteessa voi valita mahdollisista käännösratkaisuista kulttuuriseen ja tilannekontekstiin sopivimmat ratkaisut (Toury 2012 [1995]; Chesterman 2007). Kirjeenvaihtoaineiston valossa keskeisimmin esiin nouseva käytännön työtä ohjaava normi on vastaanottajan huomioiminen: kääntäjän toimintaan ja valintoihin vaikuttaa luonnollisesti se, kenelle käännetään. ${ }^{8}$

Vastaanottajan huomioiminen näkyy keskustelussa, jota kääntäjä Niilo Wainio kävi kustantajan kanssa Theodor Kolden alun perin saksaksi kirjoittaman Lutherin elämäkerran kääntämisestä:

(5) a.

Mitä käännöspalkkioon tulee, niin on ensiksikin huomioon otettava, että kun Kolden teos näyttää olevan aiottu sivistyneelle yleisölle ${ }^{9}$, sen suomentaminen ei ole aivan helppoa, sitä ei käy suomentaminen kuten tavallista hartauskirjaa. (N. Wainio 18.2.1901)

b.

Mitä suomennokseen tulee, johon arvostelijat muka eivät ole aivan tyytyväisiä, kuten sanotte, niin on huomattava, ett’ei kirja olekaan mikään helppotajuinen teos, vaan tiedemiehen käsialaa, jonkatähden käännöksenkin kieli

8. Kielitieteessä vastaanottajan huomioimiseen viitataan esim. sosiolingvistiikan käsitteellä audience design (esim. Bell 2001; ks. myös Laitinen \& Nordlund 2012). Käännöstieteessä tekstin tarkoituksen ja kommunikatiivisen luonteen ottaa huomioon niin kutsuttu skoposteoria. Sen mukaan kohdetekstin vastaanottajan tarpeet ja tiedot voivat myös poiketa lähtötekstien lukijoiden tarpeista. (Chesterman 1997: 34.)

9. Esimerkkien kursivoinnit kirjoittajan, muut merkinnät alkuperäisen tekstin mukaiset. 
muodostuu originaalin kaltaiseksi, - ainakaan en minä ole katsonut soveliaaksi ruveta sen lauserakennusta muuttelemaan. Hieman epätietoinen olen ollut, miten menetellä tiede- ja vieraskielisten sanojen suhteen, mutta en ole tahtonut noudattaa ankaraa purismia, kun nuo sanat esiintyvät melkein kaikissa sivistyskielissä. Ja onhan sitä paitsi käännöstäni siellä Teidän luonanne tarkastettu, ja olen useimmat muistutukset ottanut korrehtuuria lukeissani huomioon. (N. Wainio 20.5.1901)

Wainion kirjeessä (esim. 5b) viitataan suomennoksen vastaanottoon, joka ei kirjoittajan mukaan ollut pelkästään positiivista. Teoksen toinen arvio Valvoja-lehdessä sen sijaan on käännösratkaisujen suhteen samoilla linjoilla kuin kääntäjä itse:

(6) Kolde [- - ] on kuitenkin kauttaaltaan itsenäinen tutkija, joka tässä elämäkerrassa esittää kypsyneet tulokset parikymmenvuotisesta detaljityöstä. [- - ] Se [Kolden teos] on todellakin mitä sopivin opas perehdyttämään suurta sivistynyttä yleisöä uskonpuhdistajaan ja hänen elämäntyöhönsä. [- -] Suomennoksesta ei ole muuta kuin hyvää sanottavana. Mitä teoksen ulkoasuun tulee, olisi tämän kirjoittajalla sen suhteen ollut pari toivomusta. Ensinnäkin olisin suonut, että olisi käytetty antikva-kirjasimia fraktuuran sijasta, joka moneen tekee ikävystyttävän vaikutuksen. Ei ainakaan sille yleisölle, joka tällaisia kirjoja itselleen hankkii, "latinan" lukeminen enää tuota mitään vaikeuksia. (Valvoja 1902: 769-771)

Se, kenelle käännetään, vaikutti luonnollisesti siihen, miten käännetään: sivistyneistölle tarkoitetussa Luther-käännöksessä kieliasu saattoi kääntäjän mukaan olla lähempänä originaalia. Maininta oppineesta yleisöstä kirjan ajateltuna lukijana on jo alkuperäisen teoksen alkulauseessa (esim. 7a), jota saksalainen kustantaja oli kirjoittajalta pyytänyt ja jonka Wainio on kääntänyt sellaisenaan myös suomenkieliseen laitokseen (esim. 7b).

(7) a

Und die andere, nicht minder schwierige Aufgabe, die mir vorschwerte, war die, meine Darstellung in eine Form zu kleiden, die jedem Gebildeten verständlisch ist und doch den Gelehrten allenthalben die wissenschaftliche Begründung erkennen lässt. (Erlangen d. 28 April 1901. Dr. Th. Kolde; Kolde 1901)

b.

Ja toisena tehtäwänä10 ${ }^{10}$ joka tosin on yhtä waikea kuin edellinenkin, tawoittelin sitä, että saisin esitykselleni muodon, joka on tajuttawaa jokaiselle siwistyneelle ja jossa samalla oppineen silmä kaikkialla huomaa tieteellisen perustuksen. Saawuttakoon nyt wain tämä teokseni käännös yhtä ystäwällisen wastaanoton kuin se alkukielellä sai! (Wainion suomennos Kolden alkulauseesta)

\footnotetext{
10. Ensimmäinen Kolden alkulauseessaan mainitsema tehtävä oli sijoittaa Luther omalle aikakaudelleen eli esittää hänet historioitsijan tapaan juuri sellaisena - viisaudessaan ja heikkoudessaan - kuin hän oli. 
Myös tiedesanojen ja termien käyttö oli sallittua, koska käsitteet ja niitä vastaavat termit olivat lukijoille tuttuja muista kielistä. Wainio viittaa edellä esimerkissä $5 \mathrm{~b}$ liian ankaraan purismiin: yhtenä keskeisenä kielellisenä ideologiana oli 180o-luvulla oman kielen puhtauden vaatimus (tästä myös jäljempänä). Termien ja tiedesanojen kääntämistä suomeksi pidettiin tärkeänä kansallisen projektin osa-alueena, sillä kotikielisen ja näin ollen kansallekin läpinäkyvän termistön katsottiin lisäävän kielen demokraattisuutta (ks. esim. Paunonen 1992; Pitkänen 2008: 79-80; Pitkänen-Heikkilä 2013, 2018). Wainion tavoin myös 1800-luvun lopun kielenohjailijat yhtäältä pyrkivät suomen puhdistamiseen vieraista aineksista ja toisaalta ottivat kantaa "turhaa" tai "liian kankeaa" purismia vastaan. Myös keinotekoisten oppisanojen liiallista käyttöä siis arvosteltiin, erityisesti silloin, kun vierasperäinen sana näytti jo vakiintuneen kielenkäyttöön. (Nordlund 2004.) Kuten Mäntynen ja Kalliokoski (2018) osoittavat, keskustelua termien suomentamisesta käydään nykyäänkin.

Valvojan arviossa (esim. 6) on lisäksi kiinnostava kommentti, joka liittyy teoksen ulkoasuun ja erityisesti typografiaan. Arvioija olisi toivonut, että kirjassa olisi käytetty antiikvakirjasimia fraktuuran sijaan. Antiikva alkoi 180o-luvun loppupuolta kohti syrjäyttää fraktuurakirjasimen painotuotteissa, mutta varsinkin kansalle tarkoitetussa kirjallisuudessa, esimerkiksi hartauskirjallisuudessa, fraktuura säilyi vielä pitkään (Häggman 2001: 74; Häkkinen 1994: 27). Sen sijaan sivistyneistölle tarkoitetuissa teksteissä antiikvaa käytettiin jo aiemmin, mihin Valvojan arvioijakin viittaa. Kirjasimen käyttöön liittyi myös kulttuurisia ja poliittisia merkityksiä: fraktuura hahmotettiin uskonnollisen ja valistavan kansankirjallisuuden kirjasimeksi, kun taas antiikvalla painettu teksti saattoi kantaa merkityksiä, jotka liittyivät ruotsalaismielisyyteen ja elitististieteellisyyteen. (Mervola 1995; ks. myös Huumo 2005: 17-18 ja vastaavanlaisesta tilanteesta Ruotsissa Lindmark 2012: 87-98.)

Suurelle yleisölle tarkoitetuissa teoksissa noudatettiin Suppasen kirjeenvaihdon perusteella erilaisia käännösperiaatteita kuin sivistyneistölle tarkoitetuissa teoksissa (vrt. esim. 5a):

(8) a.

Ihmeitten maailma olisi tullut paljon parempi, jos olisin saanut sen kirjoittaa uudestaan koko teoksen. Nyt siinä on paljo sellaista, jota eivät ymmärrä muut kuin lukeneet; mutta vähän laajentamalla ja enemmän selittelemällä olisi se ollut helppo korjata. Aikaa se olisi vienyt ja maksu olisi tietysti sen mukaan kohonnut. Nyt on se vain suorastaan suomennettu, ja saatat olla jotenkin varma, että jos vain joku rupeaa kaivelemaan, kyllä sieltä löytyy muistutuksen aihetta. Kieltä olen kyllä koettanut sovitella tajuttavaksi, mikäli esityksen lyhyys on sallinut. (A. Suppanen 25.5.1892)

b.

Minusta nimittäin on tarpeen nooteissa antaa suomennos vieraskielisistä lauseista, koska ne muuten jäävät suomalaiselta lukijalta ymmärtämättä, ja sellaistakin kirjoitusta kuin tämä lukee monikin sellainen, joka ei ole lukenut yhtään vieraita kieliä. Se siitä? (A. Suppanen lokakuussa 1896) 
Ihmeitten maailma (Kronström 1892) oli Aatto Suppasen suomentama koko kansalle tarkoitettu tietokirja, joka esitteli erilaisia luonnon ja maailman ilmiöitä lukijoille. Kirjassa esiteltiin muun muassa tähdenlentoja, Suezin kanavaa, Egyptin "pyramiideja", "telefoonia" ja ihmeellisiä kiviä. Toisin kuin sivistyneistölle tarkoitetuissa teoksissa koko kansalle suunnatuissa teoksissa pidettiin tärkeänä asioiden laajempaa selittämistä ja tulkintaa esimerkiksi alaviitteiden avulla. Tällä tavalla kääntäjä tuli tekstissä vieraita kieliä ja kulttuureja tuntematonta lukijaa vastaan (ks. Paloposki 2008).

\subsection{Kieli-ideologisia kannanottoja: standardikieli-ideologia, purismi ja kankea kieli}

Kansakunnat ovat luonteeltaan kuvitteellisia yhteisöjä (Andersson 2007): ne konstruoidaan sellaisten symbolien varassa, jotka yhteisön jäsenet tunnistavat ja joiden avulla he identifioituvat kyseisen ryhmän jäseniksi. Yhteinen kansalliskieli on yhteisen historian, kulttuurin ja uskonnon ohella keskeinen kansakunnan symboli (ks. esim. Irvine \& Gal 2000; Blommaert \& Verschueren 1992: 359). Kielten standardisaatioprosessissa yksi kielimuoto kohotetaan prestiisiasemaan, jolloin se ihmisten mielessä alkaa hahmottua muita alueellisia tai sosiaalisia kielimuotoja paremmaksi, "oikeaksi" kieleksi (Vogl 2012). James ja Lesley Milroy (2012: 19) korostavat standardin ideologista luonnetta: standardikieltä voidaan pitää enemmän mielen tuotteena kuin todellisuutena ("idea in the mind rather than a reality").

Standardin rakentamiseen liittyy olennaisesti kielimuodon sisäisen variaation kaventaminen. 180o-luvun Suomessa kirjakieleen "valittiin" tiettyjen murteiden morfofonologisia tai morfologisia piirteitä (ks. esim. Paunonen 1992, 1996; Laitinen 2004; Lauerma 2004; Nordlund 2004; Litola 2015). Keskeistä standardoituun kielimuotoon pyrkiville kääntäjille oli yhtenäisyyden tavoittelu, kuten seuraavat esimerkit osoittavat:

(9) Merkitsin korr. arkin viime sivulle, että olisi hyvä, jos saisin vielä kerran tänne seuraavatkin arkit, mutta jos ette ehdi niitä enää tänne lähettämään, niin pyydän, että niissä otetaan vaarin, missä n.s. kontrakti=substantiiveissa on pääte $=$ sen (esim. taivaasen) ja muutetaan se kuuluvaksi : seen (monikko

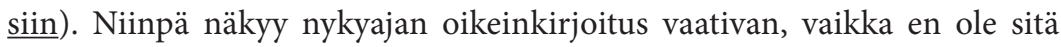
muotoa ennen käyttänyt. (N. Wainio 12.6.1901)

(10) - - Pelkään pahoin, että käännökseni on aivan ala-arvoinen. Erittäinkin minua huolettaa johdonmukaisuuden puute nimien kirjoituksessa, suurien alkukirjaiminen käytännössä, Raamatun lauseitten merkinnässä, ja käyttämisessä ja siinä, että olen toisin paikoin kirjoittanut "pelvon", toisin pelon. (H. Käkikoski 31.12.1887)

Niilo Wainio viittaa kirjeessään (esim. 9) supistumanominien illatiivimuodon vaihteluun ja vakiintumiseen nykymuotoonsa. Illatiivimuoto oli vanhassa kirjasuomessa yksivokaalinen -sen, ja pitkävokaalisen päätteen arvellaan syntyneen analogian kautta ihmiseen-tyyppisistä illatiiveista, joissa vartalovokaalin (ihmise-en) on hahmotettu kuuluvan päätteeseen (ihmi-seen). Lyhyttä illatiivimuotoa -sen esiintyi teksteissä 
kautta 180o-luvun (Verronen 1969: 88-89), ja muotoon otti kantaa myös August Ahlqvist Kieletär-lehdessään vuonna 1875. Ahlqvist oli lakikirjan toisen painoksen käsikirjoituksessa merkinnyt nomineja pitkällä päätteellä, mutta Suomalaisen Kirjallisuuden Seuran tutkijakunta oli korjannut päätteet lyhytvokaalisiksi (Kieletär 1875: 55). ${ }^{11}$ Ahlqvist puolustaa pitkää vokaalia puhekielen käytännöllä, sillä hänen mukaansa ItäSuomea lukuun ottamatta suomen puhekielessä esiintyy "Turusta Tornioon" joko pitkä vokaali tai h:llinen muoto (huoneesehen). (Verronen 1969: 92; Kohtamäki 1956: 119120; illatiivin normittamisesta ja käytöstä 180o-luvun sanomalehdissä ks. Pallaskallio \& Nordlund 2018.)

Hilda Käkikoski mainitsee kirjeessään (esim. 10) k:n astevaihtelun, joka oli eksplisiittisesti esillä $1800-l u v u n$ kielikeskusteluissa. Likvidan jälkeisen $k: n$ astevaihtelun nykyinen kirjakielen standardin kanta edustaa toisissa äänneympäristöissä itämurteista katomuotoa (esim. pelko : pelon), toisissa länsimurteista muotoa, jossa vahvaa astetta edustaa heikossa asteessa $j$ (kurki : kurjen). Kuten Käkikosken kirje osoittaa, 180o-luvulla muodoissa ilmeni vielä vaihtelua. Vaihtelua esiintyi myös painetuissa teksteissä, esimerkiksi Topeliuksen Luonnon Kirjan käännöksessä (Pitkänen-Heikkilä 2010: 88). Ahlqvist otti kantaa $k$ :n astevaihtelumuotoihin Kieletär-lehdessään 1870-luvulla arvioidessaan Julius Krohnin suomentamaa romaania Ivanhoe. Ahlqvist (1871) esittää arviossaan kannan, jota voidaan luonnehtia etymologiseksi (ks. Paunonen 1992) ja jonka mukaan alkuperäisin ja täyteläisin muoto on aina kirjakieleen sopivin:

Se on nim. aivan selvä ja luonnollinen asia, että se murre on täydellisin ja kirjakielessä enimmin seurattava, jossa kielen äänet pehmentäissäkään eivät peräti hukkaudu, vaan korvautuvat jollakulla tavalla, niinkuin mainitussa seikassa $k$ :n pehmeillä vastoilla j:llä ja v:llä. (Kieletär 1871: 1)

180o-luvun kielimiehet rakensivat suomen kirjakieltä tietoisesti ja kävivät avoimesti keskustelua eri valinnoista. Taustaoletuksena oli ajatus standardikielen varioimattomuudesta, mutta eroja syntyi siinä, millaisin perustein eri muotojen oikeellisuutta perusteltiin. ${ }^{12}$ Edellä mainittu etymologinen kanta kytkeytyy niin kutsuttuun kieliopillisuuskantaan. Kieliopillisuuskanta näki kielen luonnonilmiöiden tapaan erilaisten lakien ohjaamana täydellisenä systeeminä, jonka säännöstön kielentutkija voi tutkimuksen kautta purkaa ja analysoida. Kieliopillisuuskannan vastakohtana voi nähdä kansankielisyyskannan, joka korosti kansanmurteiden ja puhutun kielen merkitystä kirjakielen rakentamisessa: kirjakieleen tuli hyväksyä vain muotoja, jotka todella esiintyivät kielessä. (Ks. lähemmin Setälä 2001 [1893]; Paunonen 1992, 1996; Laitinen 2004; Nordlund 2004.) Kansankielisyyskantaa edustaa edellä Ahlqvistin mielipide, jossa hän perustelee illatiivin päätteen muodostamista suomen puhekielen esiintymillä. Monet

11. Ahlqvist kuului G. Cannelinin korjaaman Ruotsin valtakunnan laki -teoksen (1867) tarkastuskuntaan ja otti useassa muussakin yhteydessä kantaa laki- ja virkakieleen (Kohtamäki 1956: 69-71).

12. Toisenlaiset äänet eivät saavuttaneet yhteisössä vastakaikua. Kannatusta kielipoliittisen valtaeliitin (esim. Suomalaisen Kirjallisuuden Seura tai akateeminen eliitti) parissa ei esimerkiksi saanut Carl Axel Gottlundin evolutionistinen ajatus, jonka mukaan kukin voi kirjoittaa kuten puhuu ja "luonnonvalinnan" kautta paras kielimuoto vähitellen vakiintuu (Sulkunen 2004: 68-74). 
morfologiaa koskevat kiistat ajoittuivat 1870 -luvulle, ja vuosisadan viimeiset vuosikymmenet näyttäisivät olleen keskeisiä muotojen vakiintumisessa (ks. Nordlund \& Pallaskallio 2017).

Käkikoski mainitsee edellä kirjeessään (esim. 10) myös nimien kirjoittamisen yhdenmukaisuuden. Ulkomaisten nimien kirjoitusasusta oli erityisesti 180o-luvun puolivälin tienoilla käyty vilkasta keskustelua: osa kielimiehistä oli sitä mieltä, että ulkomaiset nimet olisi suomennettava ja kotoutettava (esim. E. A. Ingmanin artikkelissaan vuonna 1844 esittämät Ahrikka tai Lapratouri), kun taas joidenkin mielestä oli tärkeämpää säilyttää nimissä yhteys alkuperäiseen nimeen ja sen kirjoitusasuun (esim. Fabian Collan, joka artikkelissaan vuonna 1845 kirjoitti nimien oikeudesta olla nimiä, ks. Paikkala 2004: 79-86). Keskustelun taustaoletuksena oli standardikieli-ideologian mukaisesti se, että kieliasun tulisi olla kauttaaltaan yhdenmukainen ja varioimaton. Monet 1800-luvun keskustelijoista vaativat lisäksi, että perustelujen tulee olla kaikissa tapauksissa yhtenäiset eli kaikkien nimien tulisi noudattaa samoja taivutus- ja oikeinkirjoitusperiaatteita. Vuosisadan loppuun mennessä keskustelu ulkomaisten nimien kieliasusta oli jo päättynyt ja siinä oli päädytty nykyisenkaltaiseen kompromissikantaan, jonka mukaan vakiintuneet mukaelmat ja käännökset hyväksytään mutta muut nimet kirjoitetaan alkuperämaan tavalla (mas. 117). Kokonaisesta normistosta ei siis saatu kaikkien mielen mukaisesti yhtenäistä, mutta yhdestä nimestä vakiintui käyttöön vain yksi hyväksytty muoto, joka kielenkäyttäjän tulee oppia.

Vaatimus yhden oikean kieliasun tai -muodon oppimisesta on yksi standardikielen keskeisistä ominaisuuksista. Jokaisen äidinkielisenkin puhujan tulee oppia kirjoitetun standardikielen normit erikseen normatiivisista lähteistä, joita ovat esimerkiksi koululaitos, kieliopit, sanakirjat ja kieliakatemiat. Standardoitu kirjakieli on nähty myös demokratian perustana, sillä yhteisen standardin on katsottu olevan edellytys tasavertaiseen yhteiskunnalliseen osallistumiseen ja vaikuttamiseen. (Vogl 2012; ks. myös Gal 2006, joka kiistää tämän ajatuksen.) Vain normit oikein hallitseva voi saada äänensä kuuluviin yhteiskunnassa (Vogl 2012; Cameron 2012 [1995]; Hiidenmaa 2003: 296-300; Pallaskallio \& Nordlund 2018; ks. myös Stark 2013a, 2013b).

Suurin osa suomen kirjakieltä rakentavasta eliitistä oli 1800-luvulla ruotsinkielisiä, ja suomenkielinenkin sivistyneistö oli vielä vuosisadan alkupuolella saanut koulutuksensa ruotsiksi. Myös heille ruotsin kielen käyttö oli usein suomea luontevampaa kirjallisissa yhteyksissä (Laitinen \& Nordlund 2012). Sekä ruotsin- että suomenkieliset saattoivat kirjakielen murrosvaiheen keskellä olla epävarmoja omasta kielitaidostaan ja -tajustaan. Tämä tulee esille Käkikosken kirjeenvaihdossa:

(11) Muuten minun täytyy huomauttaa yhdestä seikasta. Kun keväällä pyysin Teiltä työtä, sanoin lähteväni Sotkamoon oppimaan rikkaampaa kieltä. Evankeliumiyhdistyksen postillatyön tähden jäikin matkani sikseen, ja kieleni on siis yhtä köyhä kuin ennenkin. Sen vuoksi en täydellä luottamuksella voi pyytää Teiltä enempää työtä ennenkun pääsen rikastuttamaan kieltäni. Luen tosin joka päivä Kalevalaa ja kansan satuja, vaan ei se palkitse kansan seassa olemista. (H. Käkikoski 18.8.1888) 
Käkikosken epävarmuus suomen kielen käyttäjänä on ymmärrettävää, sillä hän oli kotoisin kaksikielisestä perheestä Lapinjärveltä, itäiseltä Uudeltamaalta, ja oli käynyt osan kouluaankin ruotsiksi. Kirjeessään hän kaiuttaa 180o-luvulla yleisesti jaettua näkemystä, jonka mukaan rikkain suomen kieli on löydettävissä idästä, kaupunkien ulkopuolelta ja kansan suusta. Samanlaista epävarmuutta suomen kielen kirjoittajina kokivat luonnollisesti monet niistä kirjoittajista, joiden äidinkieli oli ruotsi (tai jokin muu kieli). Ahlqvistin mukaan ei-äidinkielisten kirjoittajien kielenkäyttö jopa loukkasi "synnynnäisen suomalaisen kielitunnetta" (Kieletär 1871). Natiivipuhujan tasoisen kielenhallinnan tavoite on yksi standardikieli-ideologian ilmentymä. Tämä on näkynyt ja näkyy erityisen selvästi sellaisessa näkemyksessä monikielisyydestä, joka jättää muun kuin äidinkielisen puhujan tasoisen (standardi)kielitaidon näkymättömiin (Vogl 2012; Karjalainen 2015: 73).

Kuten Käkikosken kirje osoittaa, ajatus oikeasta kielestä liittyy myös kielen puhtauden ideaan. Vaikka Käkikoski itse epäilee omaa kielitajuaan, arvioi kustantajan nimittämä kielentarkastaja, pastori B. Sarlin, hänen käännösnäytteensä puhtaaksi, hyväksi ja kauniiksi:

(12) Öfversättaren beherskar finska språket alldeles såsom en gammal och van och hon nästan aldrig gjort sig skyldig till någon oklarhet i meningen tanken. Allt är klart och genomskinligt (liksom hos Luther) och språket, så mycket som jag kan bedöma, rent och gott, ofta rätt vackert. (B. Sarlin 14.1.1888)

"Oikean" kielen ideologian mukaan kullakin paikalla on jokin "puhdas" kielimuoto, jota puhuu autenttinen kielenpuhuja (Bucholtz 2003: 399, ks. Mononen 2013: 130). Autenttisuus voi ilmentyä usealla eri tavalla: Monosen (2013) tarkastelemassa inkerinsuomen kielimuodossa se liittyy Suomen kirjakielen normien mukaiseen suomeen, jossa ei esiinny venäjän vaikutusta. Perinteinen dialektologia etsi "normipuhujia" (NORM = non-mobile old rural men), joiden puhe olisi mahdollisimman aitoa ja muiden murteiden vaikutteista puhdasta (ks. Mononen 2013: 130-131; Itkonen, Leskinen, Paunonen \& Lehtinen 1983 [1969]). Nykyisin autenttisuuden ideologia näkyy myös siinä, miten autenttisiksi määriteltyjä kielimuotoja (esim. Suomessa saamen kieliä) käytetään symbolisina resursseina, joita voidaan tuotteistaa esimerkiksi turismin tarpeisiin (Karjalainen 2015; Pietikäinen \& Kelly-Holmes 2011).

"Oikean" kielen taustalla voidaan nähdä myös romantiikan ajatus kirjakielestä ideaalina ja täydellisenä kielimuotona, johon on koottu puhekielestä kaikki parhaat muodot (Rintala 1998). Tällainen näkemys vastaa hyvin tavallisten ihmisten kielikäsitystä: siinä, missä kielentutkija usein pyrkii analysoimaan kielimuotojen käyttöä ja sosiaalisia merkityksiä niitä erikseen arvottamatta, on maallikon käsityksen mukaan olemassa ideaali "hyvä kieli", joka asettuu tavallisen kielen, puhuttujen kielimuotojen ja "virheiden" yläpuolelle (Preston 2002: 64; Vaattovaara \& Soininen-Stojanov 2006: 225).

Purismi eli kielen puhdistaminen vieraista vaikutteista oli edellä esillä jo vastaanottajaa huomioivan kääntämisen yhteydessä. Werner Söderströmin kirjeenvaihdossa viitataan usein nimenomaan svetisismien esiintymiseen käännöksissä: 
(13) P.S. Kielen arvostelija sanoo: "mitä suomennokseen tulee, on siinä mahdottoman paljo orjallisia svetisimiä, jotka ovat välttämättä oikaistavat ennekuin painetaan". (W. Söderström neiti Aino Winterille 15.1.1887)

Kielen kehittämistä ja alkuvaiheen käännöksiä kuvataan usein metaforisesti uudispellon raivaukseksi tai viljelyksi (Paloposki 2007; Varpio 1993: 112-115, ks. myös edellä s. 567, miten Aatto Suppasta luonnehdittiin muistokirjoituksessa Suomen kirjallisuuden vakojen kyntäjäksi). Kirjakieltä pidettiin aluksi kankeana (ks. Paloposki \& Riikonen 2013: 601-602), kuten seuraavassa esimerkissä, jossa arvioidaan kehittyvää suomenkielistä virsirunoutta:

(14) Että Katekismuksen parantaminen ja erinomaittain virhettömäin Suomalaisten virtten teko on vaikea ja kohtaa monta vastusta, ymmärtää jokainen, joka tietää kuinka kankea suomen kieli vielä on ja kuinka monta puutetta sitä vielä valtaa. (TVS1820-30-4)

Ennen 180o-lukua kirjoitettu vanha suomen kirjakieli pohjautui pääasiassa käännöksiin ruotsin kielestä ja sisälsi näin ollen runsaasti vieraita vaikutteita. Kankeus lieneekin alkuaan liittynyt nimenomaan ruotsinmukaisiin rakenteisiin (esim. 15a-b) ja on sittemmin laajentunut tarkoittamaan mitä tahansa rakenteellisesti raskasta ilmaisua $(15 \mathrm{c}-\mathrm{e})$

(15) a.

Mitä tuohon pohjalais-osakunnan suomalaiseen painokseen tulee, on siinä kieli tosiaan niin kankeata ja ruotsinvoittoista, että tekisi mieli luulemaan sitä Snellmanin itsensä tekemäksi - -. (A. Suppanen 25.11.1896)

b.

Sangen luonnollista on kuitenkin, että niin hywin asetukset kuin tuomioistuimen asiakirjat suomennoksissa tuntuwat paljon kankeammilta kuin alkuperäisessä ruotsinkielisessä asussaan. (Päivälehti 34, 11.2.1894)

c.

Runomittaa korolle perustaessakin ei saa kuitenkaan olla niin aivan huolimatta laajuudesta kuin näissä runoelmissa on laita, varsinkin daktyleissa, sillä siten tulee värssy raskaaksi, kankeaksi. (Kirjallinen Kuukauslehti 20.6.1867)

d.

Mitä kirjan kieleen tulee, on se ylimalkaan puhdasta ja helposti ymmärrettäwää; ainoastaan siellä täällä huomataan joku kankeampi lause, murteellinen sana tai painowirhe (Savo-Karjala 87, 1.8.1984)

e.

Mutta yhtä tärkeä kuin kielen puhtaus on myös sopiwan kirjoitustawan walitseminen. Liiaksi kokoon puristettua ja siitä syystä kankeata ja waikeatajuista 
kirjoitustapaa on kansakirjoissa aina wältettäwä, sillä se rasittaa ja wäsyttää lukijoita. (Päivälehti 78, 5.4.189o)

Kielen kankeutta tai toisaalta sujuvuutta korostava ideologia on jatkanut elämäänsä osana suomalaista kielenhuoltoa, ja myös nykyiset tietokirjallisuuden kääntäjät ja kustannustoimittajat tarttuvat tekstin editointiprosessissa kielen kankeuteen (Mäntynen 2003: 166).

Edellä käsitellyt kieli-ideologiat - standardikieli-ideologia, purismi ja "oikea" tai "kankea" kieli - ovat saman kolikon eri puolia. Heti kun kieli ja kielenkäyttö nousevat puheenaiheeksi, liikutaan ideologisella tasolla. Jo kielimuodon nimeäminen on ideologinen kannanotto: kieli on jotakin, joka voidaan erottaa muista kielistä tai kielimuodoista, ja kielimuotojen keskinäisiä suhteita voidaan arvottaa (ks. Halonen 2012). Standardikieli on ideologinen kuvitelma monoliittisestä kielimuodosta, joka nauttii erityistä arvostusta kirjallisessa yhteiskunnassa. Tätä kielimuotoa voidaan kuvata normatiivisissa oppaissa ja opettaa kielenkäyttäjille, ja sen hallinta voi olla esimerkiksi yhteiskunnallisen osallistumisen vaatimuksena (ks. Hiidenmaa 2003: 296-300; Cameron 2012 [1995]: 223; Pallaskallio \& Nordlund 2018). Virheellinen, köyhä tai kankea kieli on kielenkäyttöä, joka eri syistä ei täytä tällaisen oikean ja puhtaan ideaalikielen vaatimuksia.

\section{Kilpailevat ideologiat ja käännösprosessin moniäänisyys}

Todellisessa elämässä jokainen kääntäjä toimii aina erilaisten normien ja ideologioiden ristivedossa. Werner Söderströmin kaltaiset kaupalliset kustantamot syntyivät vasta 1800 -luvun lopussa, jolloin vilkkain ja näkyvin kielikeskustelu alkoi jo hiipua. Vuosisadan alkupuolta sen sijaan leimasi positiivinen ja idealistinen ajatus kirjakielen rikastamisesta eri tavoin, ja esimerkiksi morfofonologiseen vaihteluun suhtauduttiin vielä melko maltillisesti (ks. Nordlund \& Pallaskallio 2017; Pallaskallio \& Nordlund 2018; ks. myös Lauerma 2012). Tiukempi normittaminen ja morfologinen vakiintuminen ajoittuvat vuosisadan puolivälin tienoille, käytyjen debattien määrästä ja näkyvyydestä päätellen 1860-luvun lopusta 188o-luvulle.'13 Tähän kauteen ajoittuvat muun muassa Suomalaisen Kirjallisuuden Seuran Kielitieteellisen osakunnan perustaminen, August Ahlqvistin oma lehti Kieletär sekä Ahlqvistin käymät kielipoliittiset debatit esimerkiksi Yrjö Koskisen, Julius Krohnin ja A. W. Ingmanin kanssa.

Tässä tutkimuksessa tarkastelun kohteena ovat olleet 1900-luvun vaihteessa toimineet Werner Söderströmin kääntäjät. Heidän ja kustantajan välisessä kirjeenvaihdossa kielikeskustelua käytiin yhä, mutta puheenaiheiksi nousivat yksittäiset muodot tai sanat, eikä normittamisesta tai tekstien editoimisesta enää käyty samanlaista periaatteellista ideologista keskustelua kuin vuosisadan puolivälissä. Kirjoittajat näyttävät

13. Morfofonologian vakiintumista havainnollistavat hyvin Topeliuksen Luonnon Kirjan käännösversiot vuosilta 1860 ja 1868. Teoksen ensimmäisessä käännöksessä esiintyi vielä runsaasti morfofonologista variaatiota, ruotsinvaikutteisuutta ja länsimurteisuuksia, jotka olivat tyypillisiä vanhalle kirjasuomelle. Vuoden 1868 painoksessa muotoihin oli tehty paljon muutoksia, mutta siinäkään morfofonologinen vaihtelu ei vielä ollut täysin vakiintunutta. (Pitkänen-Heikkilä 2010.) 
jakavan yhteisen ajatuksen yhtenäisestä kirjoitetusta standardikielestä: kieleen ovat jo vakiintuneet "oikeat" muodot ja rakenteet, ja "vääriä" pitää välttää. Tekstejä tuotettiin vuosisadan vaihteessa yhä enemmän, ja ne olivat entistä useampien lukijoiden saatavilla. Koululaitoksen lisäksi varsinkin sanomalehdistä tuli kielenkäyttöä ohjaavia normikeskuksia. Todellisessa kielenkäytössä frekventeimmät muodot saattoivat lopulta päätyä kirjakieleen kielenohjauksen aiemmista pyrkimyksistä huolimatta (ks. edellä esim. 9; Nordlund \& Pallaskallio 2017). Laajojen digitaalisten aineistojen käyttömahdollisuudet ovat kirjasuomenkin tutkimuksessa koko ajan paranemassa. Niitä ja uusia menetelmiä hyödyntäen on mahdollista ryhtyä purkamaan niin kutsuttua varhaisnykysuomen kauden kielellistä kehitystä, joka vaikuttaa huomattavasti monipolvisemmalta kuin olemassa oleva tutkimus ja aineistot antavat ymmärtää. (Nordlund \& Pallaskallio 2017; Pallaskallio \& Nordlund 2018.)

Käännösprosessin moniäänisyys ja normiristiriidat voivat tulla esiin teosten vastaanotossa, joka ei tässä tutkimuksessa ole ollut analyysin kohteena. Esimerkiksi Päivälehdessä 1892 arvioitiin Suppasen suomentaman norjalaisen Jonas Dahlin romaanin olevan "kankea", "orjamainen käännös", "virheellinen" ja "raskas" (Päivälehti 22.10.1892). Suppanen itse puolusti käännöstään kertomalla pyrkineensä noudattamaan lähtökielen rakenteita: "Minä puolestani olen koettanut säilyttää niin paljon kuin mahdollista alkuteoksen kielen käänteitä, vaikkapa ne tuntukootkin vähän oudoilta suomen kielessä" (Päivälehti 25.10.1892). Suppasen käännösratkaisu johti siis ristiriitaan puhtaan kielen ideologian kanssa. Sanomalehdessä debatteja käytiin julkisesti, ja kirjeenvaihto, jossa asioita pohdittiin huomattavasti pienemmässä piirissä, voikin joskus kertoa enemmän käytännön todellisuudesta, jossa ihmiset elivät. Varsinkin Suppasen kirjeenvaihdosta käy selvästi ilmi, että kääntäjän omat ihanteet joutuivat usein koetukselle kiireisten aikataulujen aiheuttaminen paineiden vuoksi. Kun kirjeissä käytiin keskustelua teosten arvioista, esille nousi yleensä aikapula: jos työhön olisi voinut käyttää enemmän aikaa, lopputulos olisi ollut parempi, suomalaisempi. Kirjeet valottavat arjen ristiriitoja. Suppasen kaltaiselle ammattikääntäjälle käännöstyö oli kutsumuksen lisäksi elinkeino, jonka oli tarkoitus tuoda myös "kukkaron täytettä".

\section{Lähteet}

\section{Aineistolähteet}

Collan, FABIAN 1845: Hafva utländska namn i Finsk skrift någon rätt och möjlighet att bibehålla sin egenskap af namn? - Saima 31.7.1845 ja 7.8.1845.

InGMAN, E. A. 1844: Om främmande namns skrifning på Finska. - Suomi 1844 s. 24-216.

Kaiku 27.1.1883. Kansalliskirjaston digitaaliset aineistot. https://digi.kansalliskirjasto.fi.

Kirjallinen Kuukauslehti 20.6.1867. Kansalliskirjaston digitaaliset aineistot. https://digi.kansalliskirjasto.fi.

Kolde, Theodor 1901: Martti Luther. Elämäkerta. 1 osa. Suomentanut Niilo E. Wainio. Helsinki: WSOY.

Kronström, Halfdan 1892: Ihmeitten maailma. Suomentanut Aatto Suppanen. Helsinki: WSOY. 
NordLUnd Kääntäjien kirjeenvaihto, suomentamisen normit ja kieli-ideologiat

Päivälehti 5.4.189o. Kansalliskirjaston digitaaliset aineistot. https://digi.kansalliskirjasto.fi.

22.10.1892. Kansalliskirjaston digitaaliset aineistot. https://digi.kansalliskirjasto.fi.

- 25.10.1892. Kansalliskirjaston digitaaliset aineistot. https://digi.kansalliskirjasto.fi.

— 11.2.1894. Kansalliskirjaston digitaaliset aineistot. https://digi.kansalliskirjasto.fi.

Ruotzin Waldacunnan Laki. Seitsemäs, Gustaf Cannelinin korjaama painos. Helsinki 1867.

Savo-Karjala 1.8.1984. Kansalliskirjaston digitaaliset aineistot. https://digi.kansalliskirjasto.fi.

Suomalaisen Kirjallisuuden Seura, Kirjallisuusarkisto. Hilda Käkikosken kirjeet.

TOPELIUs, ZACHARIAS 1860: Luonnon-kirja ala-alkeiskouluin tarpeeksi. Kääntänyt Johan Bäckwall. Helsinki: Suomalaisen Kirjallisuuden Seura.

— 1868: Luonnon-kirja ala-alkeiskouluin tarpeeksi. Neljäs, parannettu painos. Kääntänyt Johan Bäckwall. Helsinki: Suomalaisen Kirjallisuuden Seura.

TVS1820 = Turun Viikko-Sanomat [tekstikorpus]. Sisältyy kokoelmaan Varhaisnykysuomen korpus: Turun Viikko-Sanomat. Helsinki: Kotimaisten kielten keskus. http://kaino.kotus. fi/korpus/18oo/meta/tvs/tvs1820_rdf.xml (1.6.2018).

Uusi Suometar 4.2.1898. Kansalliskirjaston digitaaliset aineistot. https://digi.kansalliskirjasto.fi. Valvoja 1902 s. 769-771. Kansalliskirjaston digitaaliset aineistot. https://digi.kansalliskirjasto.fi. WSOY:n arkisto. Kirjailijoiden kirjeet. Johdon kirjeenvaihtoa. Werner Söderströmin kustantajavuodet. Kansio 1. Y. A. Jäntin kokoelma. Päivälehden museo.

\section{Kirjallisuuslähteet}

Ahlqvist, August 1871-1875: Kieletär. Tutkimuksia, arvosteluja ja muistutuksia Suomen kirjallisuuden ja kielitieteen alalta I-VII. Helsinki. [Tekstikorpus]. Helsinki: Kotimaisten kielten keskus. http://kaino.kotus.fi/korpus/18oo/meta/ahlqvist/ahlqvist_coll_rdf.xml (1.6.2018).

Ahtis A ARI, EevA 1997: Käkikoski, Hilda (1864-1912) - kansanedustaja, opettaja, kirjailija. Kansallisbiografia-verkkojulkaisu. Helsinki: Suomalaisen Kirjallisuuden Seura. http:// www.kansallisbiografia.fi.libproxy.helsinki.fi/kb/artikkeli/2828/ (19.6.2018).

Alvstad, Cecilia - Greenall, Annjo K. - Jansen, Hanne - Taivalkoski-Shilov, KRISTIINA toim. 2017: Textual and contextual voices of translation. Amsterdam: John Benjamins.

ANdersson, Benedict 2007 [1991]: Kuvitellut yhteisöt. Nationalismin alkuperän ja leviämisen tarkastelua. Suomentanut Joel Kuortti. Tampere: Vastapaino.

Bell, Alan 2001: Back in style. Reworking audience design. - Penelope Eckert \& John R. Rickford (toim.), Style and sociolinguistic variation s. 139-169. Cambridge: Cambridge University Press.

Blommaert, Jan - Verschueren, Jef 1992: The role of language in European nationalist ideologies. - Pragmatics 2 s. 355-375.

Bucholtz, MAry 2003: Sociolinguistic nostalgia and the authenticication of identity. - Journal of Sociolinguistics 7 s. 398-416.

Buzelin, Hélène 2007: Translations in the making. - Michaela Wolf \& Alexandra Fukari (toim.), Constructing a sociogy of translation s. 135-169. Amsterdam: John Benjamins.

Cameron, Deborah 2012 [1995]: Verbal hygiene. Toinen painos. Lontoo: Routledge.

Chesterman, Andrew 1997: Memes of translation. The spread of ideas in translation theory. Amsterdam: John Benjamins.

— 2007: Kääntämisen normit. - Hannu Riikonen \& Outi Paloposki (toim.), Suomennoskirjallisuuden historia 2 s. 357-364. Helsinki: Suomalaisen Kirjallisuuden Seura. 
GAL, SUSAN 2006: Contradictions of standard language in Europe. Implications for the study of practices and publics. - Social Anthropology 14 s. 163-181.

НАкА Ӓ̈̈, Jy Rк 2004: Kirjojen välittäminen lukijoille 180o-luvun alun Suomessa. - Katja Huumo, Lea Laitinen \& Outi Paloposki (toim.), Yhteistä kieltä tekemässä. Näkökulmia suomen kirjakielen kehitykseen 180o-luvulla. Helsinki: Suomalaisen Kirjallisuuden Seura.

Halonen, Mia 2012: Rikkinäisiä ja likaisia. Kieli-ideologiset prosessit kielentutkimuksen diskursseissa. - Virittäjä 116 s. 443-462.

Hartama-Heinonen, Ritva 1995: Translators' prefaces - a key to translation? - Folia translatologica. International Series of Translation Studies 4 s. 33-42.

HindenmaA, Pirjo 2003: Suomen kieli. Who cares? Helsinki: Otava.

Huumo, Katja 2005: "Perkeleen kieli"-suomen kieli ja poliittisesti korrekti tiede 18oo-luvulla. Bidrag till kännedom av Finlands natur och folk 166. Helsinki: Suomen Tiedeseura.

Huumo, Katja - Laitinen, Lea - Paloposki, Outi (toim.) 2004: Yhteistä kieltä tekemässä. Näkökulmia suomen kirjakielen kehitykseen 18oo-luvulla. Helsinki: Suomalaisen Kirjallisuuden Seura.

Häggman, KaI 2001: Piispankadulta Bulevardille. Werner Söderström Osakeyhtiö 1878-1939. Helsinki: WSOY.

2008: Paras tawara maailmassa. Suomalainen kustannustoiminta 180o-luvulta 200oluvulle. Helsinki: Otava.

HÄKKInen, KaISA 1994: Agricolasta nykykieleen. Helsinki: WSOY.

IRVINE, JUdith - GAL, SUSAN 2000: Language ideology and linguistic differentiation. - Paul Kroskrity (toim.), Regimes of language. Ideologies, policies and language s. 25-83. Santa Fe: School of American Research Press.

Itkonen, Terho - Leskinen, Heikki - Paunonen, Heikki - Lehtinen, Tapani 1983 [1969]: Muoto-opin keruuopas. Toinen painos. Helsinki: Suomalaisen Kirjallisuuden Seura.

KaARninen, Mervi 2013: “Pitäisi olla puoleksi runoilija voidakseen kirjoittaa historiaa...”. - Marja Jalava, Tiina Kinnunen \& Irma Sulkunen (toim.), Kirjoitettu kansakunta. Sukupuoli, uskonto ja kansallinen historia 19oo-luvun alkupuolen suomalaisessa tietokirjallisuudessa s. 149-188. Helsinki: Suomalaisen Kirjallisuuden Seura.

KARJAlainen, ReEtTA 2015: Saamen kielet pääomana monikielisellä Skábmagovat-elokuvafestivaalilla. Jyväskylä Studies in Humanities 254. Jyväskylä: Jyväskylän yliopisto. http://urn.fi/ URN:ISBN:978-951-39-6209-8.

КонтАмӓкі, IlmARI 1956: August Ahlqvist suomen kielen ja kirjallisuuden arvostelijana. Helsinki: Suomalaisen Kirjallisuuden Seura.

Koskinen, KAisA - PAloposki, Outi 2015: Sata kirjaa, tuhat suomennosta. Kaunokirjallisuuden uudelleenkääntäminen. Helsinki: Suomalaisen Kirjallisuuden Seura.

Kovala, Ur PO 2013a: Kustannustoimen kehitys 180o-luvulla suomennetun tietokirjallisuuden näkökulmasta. - Outi Paloposki \& H. K. Riikonen (toim.), Suomennetun tietokirjallisuuden historia 180o-luvulta nykypäivään s. 40-50. Helsinki: Suomalaisen Kirjallisuuden Seura.

_ 2013b: Tietokirjallisuuden suomentajakunta 180o-luvulla. - Outi Paloposki \& H. K. Riikonen (toim.), Suomennetun tietokirjallisuuden historia 180o-luvulta nykypäivään s. 50-56. Helsinki: Suomalaisen Kirjallisuuden Seura.

KUјАмӓкі, Рекка 2013: Vertaileva kääntäjä, vertaileva tutkija. Kieltenvälinen vertailu käännöstieteessä. - Leena Kolehmainen, Matti Miestamo \& Taru Nordlund (toim.), Kielten vertailun metodiikka s. 355-395. Helsinki: Suomalaisen Kirjallisuuden Seura.

Laitinen, LeA 2004: Kieltosana ja kieletär. Yhden kielikiistan kulku ja ideologiat. - Katja Huumo, Lea Laitinen \& Outi Paloposki (toim.), Yhteistä kieltä tekemässä. Näkökulmia 
suomen kirjakielen kehitykseen 18oo-luvulla s. 177-222. Helsinki: Suomalaisen Kirjallisuuden Seura.

Laitinen, Lea - Nordlund, Taru 2012: Performing identities and interaction through epistolary formulae. - Marina Dossena \& Gabriella Del Lungo Camiciotti (toim.), Letter writing in late modern Europe s. 65-88. John Benjamins: Amsterdam.

Lauerma, Petri 2004: Aluemurre vai murteiden yhdistelmä? Keskustelu kirjakielen perustasta 180o-luvun alkupuolella. - Katja Huumo, Lea Laitinen \& Outi Paloposki (toim.), Yhteistä kieltä tekemässä. Näkökulmia suomen kirjakielen kehitykseen 18oo-luvulla s. 136-176. Helsinki: Suomalaisen Kirjallisuuden Seura.

- 2012: Jakob Johan Malmbergin suomennosten kielellinen kehitys 180o-luvun kirjasuomen murroksessa. Helsinki: Kotimaisten kielten keskus. http://scripta.kotus.fi/www/verkkojulkaisut/julk31/kristityn_vaellus_varhaisnykysuomen_merkinnassa.pdf.

Lindmark, DANIEL 2012: Från fraktur till antikva. Tryckkulturens modernisering i Sverige på 180o-talet. - Ann-Catrine Edlund (toim.), Att läsa och att skriva. Två vågor av vardagligt skriftbruk i Norden 1800-2000 s. 87-100. Nordliga studier 3. Umeå: Umeå universitet.

Litola, Katja 2015: Vastoinjärkinen komitatiivi. Kiista komitativin yksiköstä kansalliskielen projektissa. Suomen kielen pro gradu -tutkielma. Helsingin yliopisto. http://urn.fi/ URN:NBN:fi-fe201505128111.

LuUKKANen, TARJA-LiISA 2016: Mitä maalaiskansa luki? Kirjasto, kirjat ja kirjoja lukeva yhteisö Karstulassa 1861-1918. Helsinki: Suomalaisen Kirjallisuuden Seura.

Mervola, PeкKA 1995: Kirja, kirjavampi, sanomalehti. Ulkoasukierre ja suomalaisten sanomalehtien ulkoasu 1771-1994. Helsinki: Suomen Historiallinen Seura.

Milroy, James - Milroy, Leslie 2012: Authority in language. Investigating standard English. Uudistettu painos. London: Routledge.

MONONEN, KAARINA 2013: Inkerinsuomalaisten suomen käyttö Pietarissa ja sen lähialueilla. Helsinki: Suomen kielen, suomalais-ugrilaisten ja pohjoismaisten kielten ja kirjallisuuksien laitos. http://urn.fi/URN:ISBN:978-952-10-8657-1.

Mäntynen, ANne 2003: Miten kielestä kerrotaan. Kielijuttujen retoriikkaa. Helsinki: Suomalaisen Kirjallisuuden Seura.

— 2012: Kieli-ideologiat käytännössä. Sanajärjestyksen normittuminen tietokirjojen suomennostyössä. - Virittäjä 116 s. 378-409.

Mäntynen, Anne - Halonen, Mia - Pietikäinen, Sari - Solin, Anna 2012: Kieliideologioiden teoriaa ja käytäntöä. - Virittäjä 116 s. 325-348.

Mäntynen, Anne - KALliokoski, Jyrki 2018: Dialogia käsitteiden valinnasta ja käytöstä. Kieli-ideologiat tiedekirjallisuuden suomennostyössä. - Virittäjä 122 s. 493-522. https:// doi.org/10.23982/vir.60903.

NORDLUND, TARU 2004: Arat taimet ja ankarat puutarhurit. 1800-luvun lopun kielikeskustelun metaforat ja kieli-ideologiat. - Katja Huumo, Lea Laitinen \& Outi Paloposki (toim.), Yhteistä kieltä tekemässä. Näkökulmia suomen kirjakielen kehitykseen 18oo-luvulla s. 286-322. Helsinki: Suomalaisen Kirjallisuuden Seura.

— 2013: Kirjeet. Keskustelua yli ajan ja paikan. - Lea Laitinen \& Kati Mikkola (toim.), Kynällä kyntäjät. Kansan kirjallistuminen 180o-luvun Suomessa s. 107-138. Helsinki: Suomalaisen Kirjallisuuden Seura.

Nordlund, Taru - Pallaskallio, Ritva 2017: Competing norms and standards. Methodological triangulation in the study of language planning in nineteenth-century Finland. - Anita Auer, Arja Nummi, Minna Palander-Collin \& Tanja Säily (toim.), Exploring future paths for historical sociolinguistics s. 131-156. Advances in Historical Sociolin- 
guistics 7. Amsterdam: John Benjamins.

PAikкAla, SiRkка 2004: Kotoista vai kansainvälistä? Keskustelu ulkomaisista nimistä 180o-luvun lehdistössä. - Katja Huumo, Lea Laitinen \& Outi Paloposki (toim.), Yhteistä kieltä tekemässä. Näkökulmia suomen kirjakielen kehitykseen 18oo-luvulla s. 73-135. Helsinki: Suomalaisen Kirjallisuuden Seura.

Pallaskallio, Ritva - Nordlund, TARu 2018: Maaseutukirjeestä uutistekstiksi sosiolingvistiikan ja diskurssintutkimuksen rajapinnalla. - Toini Rahtu, Susanna Shore \& Mikko T. Virtanen (toim.), Kirjoitettu vuorovaikutus s. 217-248. Helsinki: Suomalaisen Kirjallisuuden Seura.

PAloposki, Outi 2001: Past visions, completed missions. Early literary translators working into Finnish. - Pirjo Kukkonen \& Ritva Hartama-Heinonen (toim.), Mission, vision, strategies, values s. 171-178. Helsinki: Yliopistopaino.

2004: Suomennoskirjallisuus 180o-luvun alkupuolella. - Katja Huumo, Lea Laitinen \& Outi Paloposki (toim.), Yhteistä kieltä tekemässä. Näkökulmia suomen kirjakielen kehitykseen 180o-luvulla s. 41-72. Helsinki: Suomalaisen Kirjallisuuden Seura.

2007: Suomentaminen ja suomennokset 18oo-luvulla. - H. K. Riikonen, Urpo Kovala, Pekka Kujamäki \& Outi Paloposki (toim.), Suomennoskirjallisuuden historia 1 s. 102-126. Helsinki: Suomalaisen Kirjallisuuden Seura.

— 2008: Kääntäjät, koulutus ja kansanvalistus. - Kalle Konttinen, Minna Kumpulainen \& Tuija Luokkakallio (toim.), MikaEL. Kääntämisen ja tulkkauksen tutkimuksen symposiumin verkkojulkaisu 2. https://www.sktl.fi/@Bin/41029/Paloposki.pdf (1.6.2018).

2013: Edlundin kustantamo - ensimmäinen suomalainen suurkustantamo. - Outi Paloposki \& H. K. Riikonen (toim.), Suomennetun tietokirjallisuuden historia 180o-luvulta nykypäivään s. 57-65. Helsinki: Suomalaisen Kirjallisuuden Seura.

Paloposki, Outi - Riıkonen, H. K. 2013: Suomennetun tietokirjallisuuden kritiikistä. - Outi Paloposki \& H. K. Riikonen (toim.), Suomennetun tietokirjallisuuden historia 180o-luvulta nykypäivään s. 599-616. Helsinki: Suomalaisen Kirjallisuuden Seura.

Paunonen, Heıкк 1992: Kielettären koulijat. - Valma Yli-Vakkuri, Maija Länsimäki \& Aarre Nyman (toim.), Yhteiskunta muuttuu - kieli muuttuu s. 150-175. Helsinki: WSOY.

— 1996: Suomen kielen ohjailun myytit ja stereotypiat. - Virittäjä 100 s. 544-555.

Pietikäinen, Sari - Kelly-Holmes, Helen 2011: The local political economy of languages in a Sámi tourism destination. Authenticity and mobility in the labelling of souvenirs. - Journal of Sociolinguistics 15 s. 323-349.

PItKänen, KAARINA 2008: Suomi kasvitieteen kieleksi. Elias Lönnrot termistön kehittäjänä. Helsinki: Suomalaisen Kirjallisuuden Seura.

PitKäNen-HeikKILÄ, KAARINA 2010: Suomentaja normien ylläpitäjänä ja rakentajana - Johan Bäckvall ja Topeliuksen Luonnon-kirjan suomennosprosessi. - Sirkka Saarinen, Kirsti Siitonen \& Tanja Vaittinen (toim.), Sanoista kirjakieliin. Juhlakirja Kaisa Häkkiselle 17. marraskuuta 2010 s. 81-95. Helsinki: Suomalais-Ugrilainen Seura.

2013: Tietokirjojen suomentajat terminologian kehittäjinä ja vakiinnuttajina. - Outi Paloposki \& H. K. Riikonen (toim.), Suomennetun tietokirjallisuuden historia 18oo-luvulta nykypäivään s. 66-82. Helsinki: Suomalaisen Kirjallisuuden Seura.

2018: Tiedesanaston suomentamista koskevat normit. Eläintaksonomisen sanaston kehittämisestä 18oo-luvulla ja 200o-luvulla. - Virittäjä 122 s. 523-56o. https://doi.org/10.23982/ vir.57006.

Preston, Dennis R. 2002: Language with an attitude. - J. K. Chambers, Peter Trudgill \& Natalie Schilling-Estes (toim.), The handbook of language variation and change s. 40-66. 
Oxford: Blackwell Publishers.

Pym, Anthony 1998: Method in translation theory. Manchester: St. Jerome Publishing.

Riıkonen, H. K. 2013: Niilo E. Wainio (1860-1931). - Outi Paloposki \& H. K. Riikonen (toim.), Suomennetun tietokirjallisuuden historia 180o-luvulta nykypäivään s. 95-97. Helsinki: Suomalaisen Kirjallisuuden Seura.

Rintala, Pärvi 1998: Kielikäsitys ja kielenohjailu. - Sananjalka 40 s. 47-64.

SaArikivi, Susanna 2005: Suomentajana 180o-luvun lopulla. Antti Jalavan ja Aatto Suppasen näkemyksiä ja kokemuksia. Ranskan kielen kääntämisen ja tulkkauksen pro gradu -tutkielma. Turun yliopisto.

SEtÄLÄ, E. N. 2001 [1893]: Oikeakielisyydestä suomen kielen käytäntöön katsoen. - Toni Suutari \& Merja Salo (toim.), Castrénin perilliset. Helsingin yliopiston suomen ja sen sukukielten professorit 1851-2001 s. 125-143. Helsinki: Helsingin yliopiston suomen kielen laitos.

Siponkoski, Nestori 2014: Translation under negotiation. The textual interplay of translators and editors in contemporary Finnish Shakespeare translation. Acta Wasaensia 304. Vaasa: Vaasan yliopisto. http://urn.fi/URN:ISBN:978-952-476-546-6:.

Sorvali, Irma 2007: Suppanen Aatto (1855-1898) - kääntäjä, kirjailija, toimittaja. Kansallisbiografia-verkkojulkaisu. Helsinki: Suomalaisen Kirjallisuuden Seura. http://www.kansallisbiografia.fi.libproxy.helsinki.fi/kb/artikkeli/285o/ (19.5.2018).

STARK, LAURA 2013a: An early virtual community resists secularization. Wolmar SchildtKilpinen's Kansan lehti 1868-1870. - Ethnologia Fennica 40 s. 6-22.

_ 2013b: Sanomalehtien maaseutukirjeet. Itseilmaisun into ja lehdistön portinvartijat. - Lea Laitinen \& Kati Mikkola (toim.), Kynällä kyntäjät. Kansan kirjallistuminen 18ooluvun Suomessa s. 145-177. Helsinki: Suomalaisen Kirjallisuuden Seura.

Sulkunen, Irma 2004: Suomalaisen Kirjallisuuden Seura 1831-1892. Helsinki: Suomalaisen Kirjallisuuden Seura.

Toury, Gideon 2012 [1995]: Descriptive translation studies and beyond. Amsterdam: John Benjamins. https://doi.org/10.1075/btl.100.

VaAttovaara, Johanna - Soininen-Stojanov, Henna 20o6: Pääkaupunkiseudulla kasvaneiden kotiseuturajaukset ja kielelliset asenteet. - Kaisu Juusela \& Katariina Nisula (toim.), Helsinki kieliyhteisönä s. 223-254. Helsinki: Helsingin yliopiston suomen kielen ja kotimaisen kirjallisuuden laitos.

VARPIO, YRJÖ 1993: August Ahlqvist ja 180o-luvun puolivälin kielellinen lukukoodi Suomessa. - Jaakko Anhava (toim.), Suomen kieli, suomen mieli. August Ahlqvist vaikuttajana s. 109-123. Helsinki: Suomalaisen Kirjallisuuden Seura.

Verronen, MarJe 1969: Varhaisnykysuomen loppupuolen taivutusoppia. Suomen kielen pro gradu -tutkielma. Turun yliopisto.

VOGL, ULRIKE 2012: Multilingualism in a standard language culture. - Mathias Hüning, Ulrike Vogl \& Oliver Molinier (toim.), Standard languages and multilingualism in European history s. 1-42. Amsterdam: John Benjamins. 


\section{Norms and ideologies of translation in light of correspondence between publisher and translator in $19^{\text {th }}$-century Finland}

This article analyses the ideologies and norms that guided the translation of works of non-fiction in $19^{\text {th }}$-century Finland. As a case study the article analyses the processes involved in the publication of non-fiction at the Werner Söderström Ltd publishing house at the end of the $19^{\text {th }}$ century. The research takes as its base theories examining the sociology and history of translation. It also aims to evaluate how and to what extent historical translation processes can be reconstructed. Translation is approached as a collaborative process involving various actors: publisher, translator, language editor, and expert reader. The data consists of correspondence between publisher and translator that deals with matters of translation or language. This correspondence sheds light on the everyday life of the translator and the socially accepted norms and ideologies that guide the translation process. It also reveals the stance of publishers concerning the choice of translator, a factor that can lead to very different end products.

The analysis shows that, as professional writers, translators at the end of the $19^{\text {th }}$ century were well aware of contemporary translational norms. In practice, translators were caught between various conflicting pressures - regarding, for instance, questions such as whether one should follow the original text as close as possible to preserve its unique style or assimilate the text to a Finnish context to help the reader. The data also shows that translators were well aware of linguistic norms; they were acquainted with current and past debates, and in assimilating their use of language they remained sensitive to prevailing norms. 


\section{Kääntäjien kirjeenvaihto, suomentamisen normit ja kieli-ideologiat 1800-luvun lopun Suomessa}

Artikkeli käsittelee suomentamiseen liittyviä ideologioita ja normeja 180o-luvun tietokirjallisuudessa. Tapaustutkimuksena on Werner Söderström Osakeyhtiön tietokirjojen suomennostoiminta $1800-$ luvun lopulla. Tutkimus kytkeytyy kääntämisen sosiologiaan ja historiaan, ja siinä arvioidaan myös, miten ja missä määrin historiallisia käännösprosesseja voidaan rekonstruoida. Käännösprosesseja lähestytään tarkastelemalla eri toimijoiden - kustantaja, kääntäjä, kieliasiantuntija, tekstin arvioija - osuutta käännösprosessissa. Tutkimuksen aineistona on kustantajan ja kääntäjän kääntämistä ja kielellisiä valintoja käsittelevä kirjeenvaihto, jonka avulla on mahdollista valottaa eri suunnista kääntäjän arkea, yhteisöllisiä arvoja ja normeja käännösvalintojen taustalla sekä niitä henkilökohtaisia asenteita, jotka ohjaavat kääntäjiä erilaisiin valintoihin.

Analyysin tuloksena voi päätellä, että ammattikirjoittajina kääntäjät olivat hyvin tietoisia erilaisista kielellisistä ja kääntämiseen liittyvistä normeista. Käytännön työssä kääntäjät toimivat kuitenkin usein erilaisten normien ristipaineessa, jolloin vastakkain asettuivat esimerkiksi alkuteoksen luonteen säilyttäminen ja toisaalta sen kotouttaminen. Kääntäjät olivat myös tietoisia kielen vaihtelevista normeista, tunsivat käynnissä olevat kielikeskustelut ja mukauttivat herkästi kielenkäyttöään kulloinkin vallitsevien kirjakielen normien mukaiseksi.

Kirjoittajan yhteystiedot (address):

etunimi.sukunimi@helsinki.fi

Kirjoittaja on suomen kielen professori Helsingin yliopistossa. 